already has a permanent staff of about nine hundred, but it is satisfactory to know that the Council also proposes to enlist the aid of independent outside men of science if, and when, required.

\section{Institution of Electrical Engineers : Faraday Medal}

Dr. ArexAnder Russell has been awarded the eighteenth Faraday Medal by the Council of the Institution of Electrical Engineers. The medal is awarded for notable achievement in, or help to, electrical science or industry, and Dr. Russell is qualified in both respects. His works on alternating currents and the theory of cables have long been classical; not less well known are his researches on the sphere gap, and many other mathematical researches and papers communicated to the learned societies. He recently published the "Life of Lord Kelvin", whom he knew in the early days. Dr. Russell has been connected with Faraday House from its inception in 1889, and became principal in 1909. During fifty years he has helped in, or been responsible for, the training of thousands of electrical engineers, now to be found all over the world. The outstanding feature of this education has been the encouragement of men to bear their own responsibilities; many of his students, both in the early days and recently, have achieved important work even during their student days. He has been for many years a valued contributor to NATURE.

Dr. Russell is a past president of the Institution of Electrical Engineers, of the Physical Society of London, and of the Junior Institution of Engineers. $\mathrm{He}$ was elected fellow of the Royal Society in 1924 and made an honorary member of the Institution of Electrical Engineers in 1937. Later in the same year he retired from the more active work at Faraday House and became advisory principal. He thus holds available for the College his life's experience, and maintains contact with the hundreds of old students who can call in to see him, and with the thousands who can only write. We like to think that it is this aspect of his life's work, and the army of valuable men that has resulted from it, that the Council of the Institution of Electrical Engineers had in mind, not less than his mathematical researches, when the award of this year's Faraday Medal was made.

\section{Captain C. W. Hume}

Captain C. W. Hume resigned from the editorship of the Proceedings of the Physical Society on January 1, after having been responsible for that journal for a period of twenty years. A member of the reserve of Army officers, he rejoined his unit some time previously, and continued his editorial work until impending changes made it no longer possible. During his tenure of the office, he had seldom missed a Council meeting, and was usually present at science meetings, to obtain a record of the discussion on papers at first hand. He took great pains with the preparation of the Proceedings to ensure that papers should be free from ambiguity and obscurity, and printed in uniform style. His other interests were many. He founded the University of London Animal Welfare Society and the Universities Federation for Animal Welfare, and had also taken an active part at one time in the Association of Scientific Workers and the Parliamentary Science Committee, as it then was.

\section{African Studies and the War}

Notwithstanding the War, native administration in Africa must be carried on; and the problems incidental thereto are likely to become more, rather than less, insistent in the world turmoil which now prevails. For the moment, indeed, paradoxical as it may seem, circumstances probably are more favourable to African studies directed to possibilities of future development than if the end of hostilities were within measurable distance. Such, at least, would appear to be the judgment of H.M. Secretary of State for the Colonies, at whose request Lord Hailey will shortly pay a visit to a number of the British dependencies in West, East, and Central Africa to undertake an informal study of certain aspects of native administration. This investigation will carry further the work on such questions which Lord Hailey has already done during his earlier visits, when collecting material for his "African Survey". His inquiries on this occasion, which are expected to take about six months, will be directed in the main to the comparative study of forms of native administration, with special reference to their technical working and their future development. It will be of more than passing interest to see how in the judgment of so experienced an observer as Lord Hailey the diversity of conditions which will be brought under notice justify, or the reverse, the standardization of administrative methods in the interests of native advancement, and how far a more intensive study of native institutions in relation to administration than they have yet received, is demanfled.

At the close of his tour, Lord Hailey will spend a short time in Southern Rhodesia, where facilities will be afforded for an unofficial study for comparative purposes of the principles and methods of native administration followed there. This study, it is anticipated, will be of great value when further consideration is given to the difficult questions of native policy in the Rhodesias and Nyasaland, to which attention is directed in the Report of the Rhodesia-Nyasaland Royal Commission (see NATURE, 143,$829 ; 1939$ ).

\section{International Co-operation and African Studies}

INTERNATIONAL co-operation, which in recent years has contributed so markedly to progress in African studies, is now necessarily much curtailed. Nevertheless, the International Institute of African Languages and Cultures, although its existence as an international institution seemed to be threatened, has decided that, so far as possible, its work must continue. In a communication over the signature of Lord Lugard, chairman of the Executive Council, which has been circulated to the members of the Institute, the reasons for the decision are given. Science, it is pointed out, is neutral, and further, the 